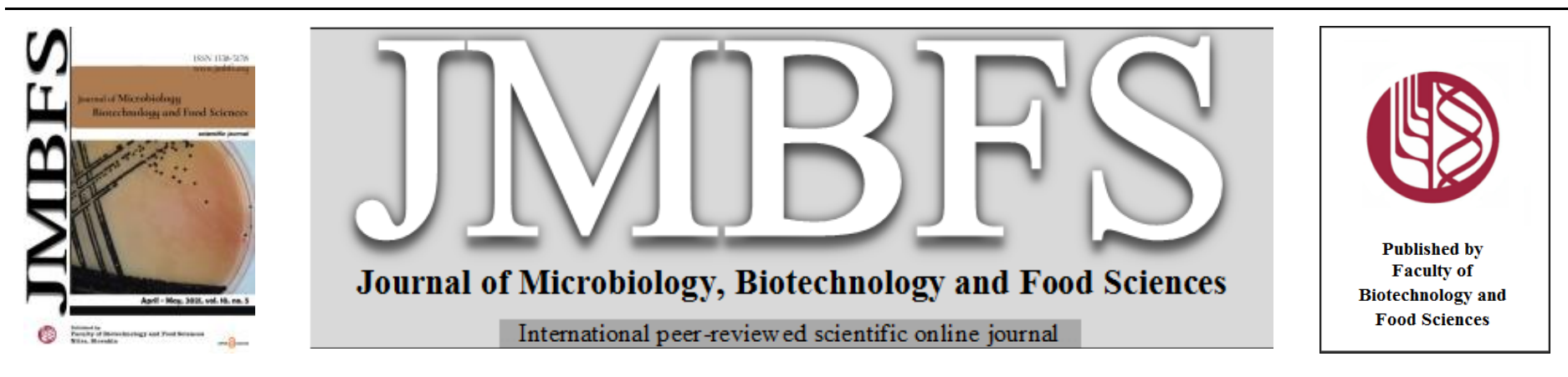

\title{
CHARACTERIZATION OF ENDOPHYTIC BACTERIA OF THE GENUS BACILLUS AND THEIR INFLUENCE ON THE GROWTH OF MAIZE (ZEA MAYS) IN VIVO
}

Nikola Lipková*, Renata Cinkocki, Jana Maková, Juraj Medo, Soňa Javoreková

Address(es): Ing. Nikola Hricáková

Slovak University of Agriculture in Nitra, Faculty of Biotechnology and Food Sciences, Department of Microbiology, Tr. A. Hlinku 2, 94976 Nitra, Slovakia, +421944739543.

*Corresponding author: nika.hricakova@gmail.com

https://doi.org/10.15414/jmbfs.3602

\section{ARTICLE INFO}

Received 19. 8. 2020

Revised 15. 2. 2021

Accepted 18. 2. 2021

Published 1. 4. 2021

Regular article OPEN $\partial_{\text {ACCESS }}$

\begin{abstract}
Bacteria with positive properties on plant vitality are also called PGPB (Plant Growth Promoting Bacteria). Their presence can be observed not only in the root area but also in the above-ground parts of plants like endophytic bacteria. The aim of our study was to characterize promoting features of bacteria from Bacillus genus and compare them with Pseudomonas simiae WCS417 (plant growth promoting strain). The work was carried out in locality Kolíňany near Nitra $\left(40^{\circ} 26^{\prime} 46^{\prime \prime} \mathrm{N}, 79^{\circ} 58^{\prime} 56^{\prime \prime} \mathrm{W}\right)$ and root samples were taken from 6 randomly selected plants of maize (Zea mays L.) in vegetative plant growth stage BBCH 14-15. Bacteria isolated from plant roots were identified and tested to biochemical parameters. From the biochemical features, we observed the detection of siderophores, determination of indole-3-acetic acid (IAA), monitoring the ability to dissolve phosphates and antifungal activity. Bacterial suspensions were applied to maize seeds and tested in vivo controlled conditions. Tested isolates were identified as Bacillus flexus, Bacillus megaterium and Bacillus subtilis. All 3 strains achieved the middle - class of phosphate solubilization index $(2.00 \leq \mathrm{SI}<4.00)$, produced phytohormone IAA and showed positive production of siderophores and inhibited growth of Fusarium culmorum to more than 50\%. All differences between tested strains and control strain P. simiae WCS417 were also statistically confirmed. All strains showed positive results in monitoring plant growth promoting properties. The effect of three Bacillus strains on maize seeds in vivo conditions showed significant differences in root length $(\mathrm{P}<0.0001)$ and weight of the young plant $(\mathrm{P}<0.001)$ compared to control.
\end{abstract}

Keywords: bacteria, plant vitality, identification, maize

\section{INTRODUCTION}

Bacterial strains that have beneficial effects on plant growth and vitality are characterized as beneficial plant-associated bacteria colonize the rhizosphere (rhizobacteria), the phyllosphere (epiphytes), and the inside of plant tissues (endophytes) (Kobayashi and Palumbo, 2000). Depending on their effect on the host plant, bacteria can be categorized into three groups: plant-growth promoting (PGPB), plant-growth inhibiting, and plant-growth neutral (Sturz et al., 2000). Numerous microbes are naturally beneficial to plants and help to sustain plant growth during abiotic and biotic stresses (Sharma et al., 2014).

The beneficial effects of PGPBs are generally observed by the occurrence of an increase in germination rates, root growth, yield, leaf area, chlorophyll content, magnesium content, nitrogen content, hydraulic activity tolerance to drought, shoot and root dry weights. PGPB can promote plant growth directly or indirectly (Glick, 1995). Recent studies showed that the direct mechanisms involve improved uptake of nutrients such as nitrogen and phosphorus, production of plant hormones such as indole-3-acetic acid (IAA), gibberellins and cytokinins. On the other hand, indirect mechanisms mainly consist of production of iron chelating agents, cyanides and siderophores. Besides, production of various antimicrobial metabolites is also grouped into the indirect mechanisms (Tonelli et al., 2017; Radhakrishnan and Lee, 2016). Plants are constantly involved in interactions with a wide range of bacteria, which belong to the Acetobacter, Azospirillum, Azotobacter, Bacillus or Pseudomonas genera (Jones et al., 2007). Among several species of PGPB, the Pseudomonas and Bacillus spp. have been identified as the predominant genus (Kang et al., 2015). Bacillus spp. are gram positive, ubiquitous in nature and recovered from all niches in the environment. These species have also been used to prepare industrial and agricultural products (Lyngwi and Joshi, 2014). Endophytic bacteria are isolated from various parts of the plant above and below ground but the highest number of endophytic bacteria were observed in the roots (Afzal et al., 2019). The Bacillus spp. associated with plant roots and rhizosphere promoted plant growth (Beauregard et al., 2013).

The aim of this study was to test endophytic bacterial strains isolated from maize roots for plant growth promoting traits and to find differences between these strains and plant growth promoting strain Pseudomonas simiae WCS 417. We further monitored whether the results of analyses with the assumption of plant growth support cooperate with the application of bacteria in vivo to the model plant. In this study we perform the following steps: (1) identification of species isolated from maize roots, (2) testing all Bacillus strains to biochemical properties that promote plant growth and (3) monitoring of changes in plant growth after application of Bacillus strains to the maize seeds under in vivo conditions compared to Pseudomonas simiae WCS 417 (Netherlands).

\section{MATERIALS AND METHODS}

\section{Collection of root samples}

Plants of maize (Zea mays L.) for the isolation of endophytic bacteria were collected from SUA University Farm Kolinnany $\left(40^{\circ} 26^{\prime} 46^{\prime \prime} \mathrm{N}, 79^{\circ} 58^{\prime} 56^{\prime \prime} \mathrm{W}\right)$ Slovakia (Fig. 1), in plant growth stage BBCH 14-15 (growth of 2-4 true leaves) The sowing of maize was established in April 2017 and maize was once treated with the herbicides Laudisode and Lontrel.. Six randomly selected plants of maize with roots were carefully taken by sterilized spade from soil and transferred into laboratory Department of Microbiology, Faculty of Biotechnology and Food Sciences, SUA, Nitra. In the laboratory were plants separated into stems and roots. Roots were cleaned thoroughly with tap water, rinsed with deionized water and drained on absorbent towels for futher sterilization and isolation steps. 


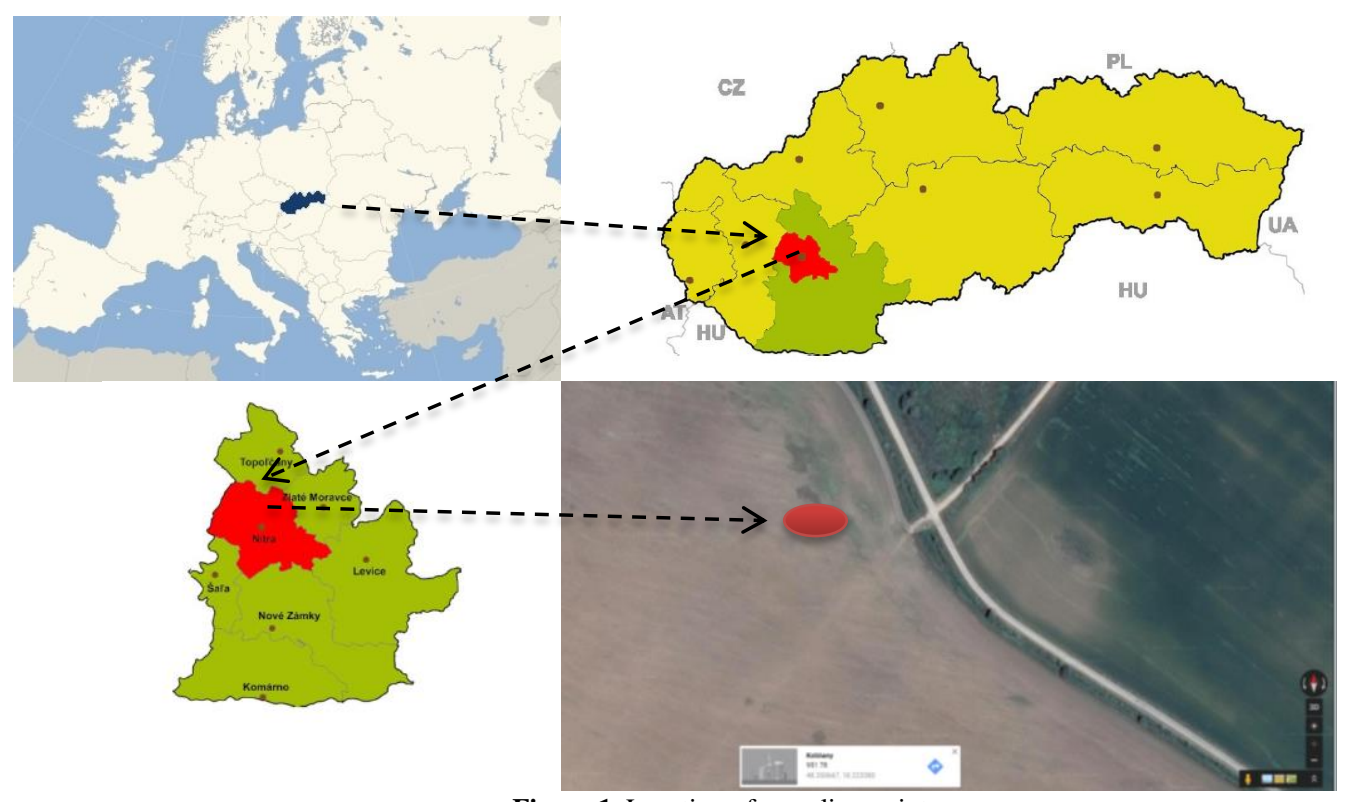

Figure 1. Location of sampling point

\section{Isolation of bacterial strains}

Root surface sterilization included the followings steps (Sun et al., 2008): to wash out the mechanical impurities roots were washed under distilled water and then surface sterilized in $99 \%$ ethanol for 1 minute and $3.125 \%$ sodium hypochloride solution for 6 minutes and followed by final wash in sterile distilled water for 3 times. Sterilized root samples were aseptically cat to small fragments which were placed on Luria-Bertani (LB) agar plates in 3 repetitions and incubated for $24 \mathrm{~h}$ at $30{ }^{\circ} \mathrm{C}$. After incubation, distinct bacterial colonies were streaked on LB agar plates to get single colonies. Thus prepared bacterial isolates were used for further testing.

\section{Molecular characterization}

DNA was extracted from 1-day-old bacterial isolates prepared by the TSA agar cultivate method. Approximately $50 \mathrm{mg}$ of each bacterial culture was placed in $200 \mu \mathrm{l}$ of PrepMan solution (Life technologies) and homogenized with glass beads on BeadBug homogenizer (Benchmark scientific). DNA from all samples was use as a DNA template in PCR reaction. The bacterial 16S rRNA genes were amplified through PCR using the universal bacterial primers $27 \mathrm{~F}$ (5' AGAGTTTGATCATGGCTCAG-3') and 1492R GGTTACCTTGTTACGACTT-3') (Nardi et al., 2004). Cycling conditions for PCR amplification (performed in thermocycler MJ Mini (Biorad, USA) were as follows: $95^{\circ} \mathrm{C}$ for $3 \mathrm{~min}$. followed by 40 cycles of $95^{\circ} \mathrm{C}$ for $30 \mathrm{~s}$, annealing at temperature $56^{\circ} \mathrm{C}$ for $30 \mathrm{~s}, 72^{\circ} \mathrm{C}$ for $90 \mathrm{~s}$ and a final elongation at $72^{\circ} \mathrm{C}$ for 10 min. Amplification products were sequenced and performed by Macrogen (South Korea). Acquired sequences were assembled and processed in MEGA 7 software (Kumar et al., 2018). Alignment was made in MUSCLE (Edgar, 2004). We used the reference sequences from Genbank database for phylogenetic analysis. A phylogenetic tree was constructed using method of Maximum likehood with substitute model Tamura-Nei (Tamura et al., 2007).

\section{Morphological, physiological and biochemical characterization}

We monitored cell morphology, gram property using Gram's staining, endospore formation, oxidase and catalase activity (Collins et al., 2004).

\section{In vitro tests for direct growth promotion traits}

Bacterial isolates were tested for these direct growth promotion traits: production of phytohormone indole-3-acetic acid (IAA) and phosphate solubilisation. Pseudomonas simiae WCS417 (Netherlands) was used as a positive control.

Production of phytohormone Indole-3-acetic acid (IAA) was evaluated according to Gordon and Weber (1951). Bacterial cultures were grown for 24 hours at 30 ${ }^{\circ} \mathrm{C}$ on Trypton Soya Agar (TSA) plates and than the concentration of each bacterial strain was standardized to $0.5 \mathrm{McFarland}\left(10^{8} \mathrm{CFU} \cdot \mathrm{ml}^{-1}\right)$. Bacteria suspension was incubated in Pikovskaya's broth with $0.2 \%$ L-tryptophan for 7 days at $30{ }^{\circ} \mathrm{C}$. The supernatant was mixed with Salkowski reagent. The mixture was incubated in the dark for 30 minutes and then examined for the development of pink colour as an indication of IAA production. The colorimetric measurement of IAA was done spectrophotometrically at $530 \mathrm{~nm}$.

Activity of bacteria to dissolve phosphates was evaluated on Pikovskaya's agar with bromophenol blue (Gupta et al., 1994). Plates were inoculated with tested bacteria and incubated for 7 days at $30{ }^{\circ} \mathrm{C}$. The yellow/clear zone around bacterial colonies showed positive solubilisation of phosphates and Solubilisation index (SI) was calculated according to Kumar and Narula (1999).

\section{In vitro test for indirect growth promotion traits}

Bacterial isolates were evaluated for these 2 traits associated with indirect growth promotion: antagonism against phytopatogenic fungi and siderophore production. In tested methods was used Pseudomonas simiae WCS417 as a positive control. Phytopathogenic fungi were inoculated on plates with Potato Dextrose agar (PDA) and incubated for 10 days at $25{ }^{\circ} \mathrm{C}$. Tested bacteria were inoculated on TSA plates and incubated 24 hours at $30{ }^{\circ} \mathrm{C}$. Bacterial suspensions were diluted to $0.5 \mathrm{McF}$ arland $\left(10^{8} \mathrm{CFU} \cdot \mathrm{ml}^{-1}\right)$ and spreaded onto the surfaces of TSA plates using sterile bacterial cell spreaders. The centre of each plate was inoculated with $9 \mathrm{~mm}$ diameter fungal plug cut with a sterilized cork-borer from a Fusarium culmorum culture. Petri dishes were incubated for 10 days at $25{ }^{\circ} \mathrm{C}$. Pseudomonas simiae WCS417 (Netherlands) was used as a positive control, sterile TSA plates as a negative control. The pathogenic fungus Fusarium culmorum 819. was obtained from Department of Plant Protection, Faculty of Agrobiology and Food Resources, SUA, Nitra.

Production of siderophores was tested according to Schwyn and Neilands (1987) using the Chrome Azurol S (CAS) medium. Each bacterial isolate was inoculated on agar plates and incubated for 7 days at $30^{\circ} \mathrm{C}$. The orange halo zone around a bacterial colony indicated siderophore production by bacteria.

\section{Growth promotion effects in vivo}

The potential PGPB strains isolated from maize roots were analysed for their ability to exhibit plant growth promotion. Firstly, the maize seeds were surface sterilized with $3.125 \% \mathrm{NaOCl}$ for two min. and followed by three washes in sterile distilled water. The organically poor soil was sterilized in autoclave in followed conditions: pressure $0.1 \mathrm{MPa}$ and temperature $121{ }^{\circ} \mathrm{C}$ for 20 minutes. Inoculants of the selected strains were prepared on TSA agar plates and incubated at $30{ }^{\circ} \mathrm{C}$ for $24 \mathrm{~h}$. Concentration of bacteria was standardized to $0.5 \mathrm{McFarland}$ $\left(10^{8}\right.$ CFU.ml $\left.{ }^{-1}\right)$ for each strain. Sterilized seeds were immersed in the bacterial suspensions for 1 hour. After soaking, the seeds were sown in the soil, $1 \mathrm{~cm}$ below the surface. A growth chamber experiment lasted 4 weeks and was carried out under controlled conditions: changes in temperature depending on the light period - 16 hours, $28{ }^{\circ} \mathrm{C}$ and dark period -8 hours, $22{ }^{\circ} \mathrm{C}$ and constant humidity in both phases was $80 \%$. As a control, seeds were treated in distilled water. As a positive control we used the strain Pseudomonas simiae WCS417 (Netherlands) 30 days after sowing plants were removed from the soil and their roots were carefully washed. The root length $(\mathrm{cm})$ and weight of the young plant $(\mathrm{g})$ were evaluated.

\section{STATISTICAL ANALYSIS}

All results are the means of three independent replicates. Analysis was carried out using the GraphPad Prism where standard error was evaluated. We used Oneway analysis of variance ANOVA to compare values from the analysis of plant growth promoting characteristics and analysis of the effect of these bacteria on maize growth performance (root length and weight of the young plant). A comparisons were done using Dunnett's test and the significant level was set at $* * * * \mathrm{P}<0.0001$ and $* * * \mathrm{P}<0.001$. 


\section{RESULTS AND DISCUSSION}

During last few years many studies focused on the isolation and characterization of bacterial strains isolated from soil or plant parts with plant growth promotion potential (Ramakrishna et al., 2019; Majeed et al., 2018; Numan et al.,2018; Olanrewaju et al., 2017; Olivares et al., 2017). These types of bacteria were classified as PGPB - Plant Growth Promoting Bacteria and we can divide them to three main groups like rhizospheric bacteria, phyllospheric bacteria and endophytic bacteria (Kuan et al., 2016). According to this fact we tested endophytic bacteria isolated from plant roots to their plant growth promoting traits. The maize root samples were taken from SUA University Farm Kolín̆any. Bacillus strains are mostly dominant in the soil around the roots (rhizospere) and inside the roots (Hallmann and Berg, 2006). Studies on the diversity of rootassociated bacteria in maize revealed extensive colonization by Bacillus strains during the active vegetative plant growth stage of the plants (Lalande et al., 1989).

Our root samples were collected during active growth stage of maize $\mathrm{BBCH} 14$ 15. From all samples we isolated 10 bacterial strains and 3 of them were identified as Bacillus megaterium (231), Bacillus flexus (239), and Bacillus subtilis (246). Similar result are observed for different plant species, including sugar cane (Ratón et al., 2012), maize (Pereira et al., 2011) and rice (Nautiyal et al., 2013). Detailed data about taxonomic affiliation of tested strains and GenBank accession numbers are situated in Table 1. The phylogenetic tree of bacterial strains constructing by using their $16 \mathrm{~S}$ rRNA sequences is shown on Figure 1.

Table 1 Taxonomic affiliation of active strains and GenBank accession numbers

\begin{tabular}{lllc}
\hline $\begin{array}{l}\text { Sample } \\
\text { Code }\end{array}$ & $\begin{array}{l}\text { Accession } \\
\text { Number }\end{array}$ & Closet relative species & \% Identity \\
\hline $\mathbf{2 3 1}$ & NR_116873.1 & $\begin{array}{l}\text { Bacillus megaterium } \text { strain } \\
\text { ATCC 14581 }\end{array}$ & $99.65 \%$ \\
\hline $\mathbf{2 3 9}$ & NR_113800.1 & $\begin{array}{l}\text { Bacillus flexus } \text { strain NBRC } \\
15715\end{array}$ & $100 \%$ \\
\hline $\mathbf{2 4 6}$ & NR_112116.2 & $\begin{array}{l}\text { Bacillus subtilis strain IAM } \\
12118\end{array}$ & $99.89 \%$ \\
\hline
\end{tabular}

Legend: 231 - Bacillus megaterium, 239 - Bacillus flexus, 246 - Bacillus subtilis

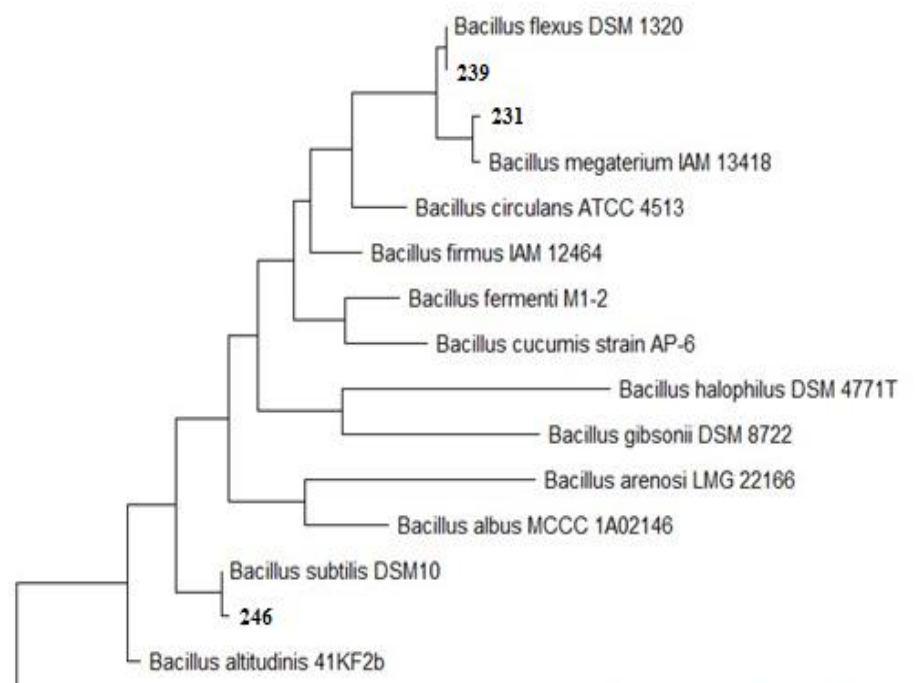

Micrococcus luteus DSM $20030^{\circ}$

Figure 2 Phylogenetic tree of $16 \mathrm{~S}$ rDNA gene sequences showing the relationships among the isolates from maize roots

Bacillus strains were examined for their morphological, physiological and biochemical properties. Relative results including cell morphology, Gram property and endospore formation, oxidase and catalase activity. All results are summarized in Table 2. In all properties we tested reference strain Pseudomonas simiae WCS417 (Netherlands).

\begin{tabular}{|c|c|c|c|c|c|}
\hline $\begin{array}{l}\text { Sample } \\
\text { code }\end{array}$ & $\begin{array}{l}\text { Cell } \\
\text { morphology }\end{array}$ & $\begin{array}{l}\text { Gram } \\
\text { property }\end{array}$ & $\begin{array}{l}\text { Endospore } \\
\text { formation }\end{array}$ & $\begin{array}{l}\text { Oxidase } \\
\text { activity }\end{array}$ & $\begin{array}{l}\text { Catalase } \\
\text { activity }\end{array}$ \\
\hline 231 & Rod & + & + & + & + \\
\hline 239 & Rod & + & + & + & + \\
\hline 246 & Rod & + & + & + & + \\
\hline 525 & Rod & - & - & + & + \\
\hline
\end{tabular}

Pseudomonas simiae WCS417

The aim of our work was to determine the effectiveness of bacteria by testing their ability to promote plant growth and apply them to seeds under in vivo conditions. For growth promotion, we tested the following: the ability to solubilize phosphates into a plant-accessible form, the production of phytohormone indole-3-acetic acid (IAA), the production of siderophores and antifungal activity. As a positive control we tested Pseudomonas simiae WCS 417 (Netherlands) strain. In the last years many publications described biologica mechanisms involved in the ability of the PGPB strain $P$. simiae WCS417 to promote plant growth and health (Desrut et al., 2020; Pieterse et al., 2020; Stringlis et al., 2019; Yu et al., 2019; Williams et al., 2018). The results of plant growth promoting direct and indirect potentials of tested Bacillus strains and reference strain Pseudomonas simiae WCS417 are shown in Table 3.

Seed germination and plant growth are influenced by the nutrients available in the soil. Plants absorb phosphorus (P) from the soil through root transporters. Available forms of $\mathrm{P}$ are also limited (Bidondo et al., 2012). Bacillus spp convert the complex form of essential nutrients, such as $\mathrm{P}$ to a simple available form that is used during uptake by plant roots. All tested strains solubilize phosphate. They are included in the group with middle phosphate solubilizaton index $(2.00<\mathrm{SI}>4.00)$ according to Kumar et al. (1999). A statistically significant difference $(\mathrm{P}<0.01)$ was observed between strain 239 (B. flexus) and P. simiae WCS417.

The presence of tryptophan and other bacterial food source compounds induces the synthesis of indole-3-acetic acid (IAA) and other hormones in bacterial populations (Glick, 2014). Plant-growth-promoting substance IAA is synthesized by Bacillus spp. and increase root and shoot cell division and elongation (Radhakrishnan and Lee, 2016). According to the IAA production assay results all 3 Bacillus isolates and Pseudomonas simiae WCS417 produce auxin from 2.07 to $5.60 \mu \mathrm{g} \cdot \mathrm{ml}^{-1}$. A statistically significant difference was observed between all Bacillus strains to the $P$. simiae WCS417. The $\mathrm{P}$ value was as follows 525-231 and 525-239 $(\mathrm{P}<0.001)$ and 525-246 $(\mathrm{P}=0,034)$. The iron-chelating properties of Bacillus spp. via siderophore production help to solubilize iron from minerals and organic compounds in rhizosphere (Nadeem et al., 2012). In the case of Pseudomonas simiae WCS417, its biological activity is mainly associated with the production of siderophores (Berendsen et al., 2015). In our study was production of siderophores positive in all tested isolates.

Maize is one of the crops that is attacked by a number of pests at all growth stages. Among the most common are microscopic fungi, especially representatives of the genus Fusarium (Javoreková et al., 2020). Genus Bacillus is well known for their antagonistic behavior by producing siderophores, $\mathrm{HCN}$, hydrolytic enzymes and antibiotics. In the Srivastava's study nine of the soybean bacterial endophytes that belong to Bacillus sp. were reported to have antifungal activities against major soil-borne plant pathogens like Rhizoctonia, Fusarium and Sclerotinium (Srivastava et al., 2016). Bacillus spp. attaches to the mycelial cell walls and damage fungal mycelium (Akram et al., 2016). In our study was protection against pathogens more than $50 \%$ in all tested isolates. Statistically significant differences were observed between all tested strains to the control strain $P$. simiae WCS417. 
Table 3 Plant growth promoting characteristics of the bacterial isolates (means \pm standard error)

\begin{tabular}{|c|c|c|c|c|}
\hline $\begin{array}{l}\text { Sample } \\
\text { Code }\end{array}$ & $\begin{array}{l}\text { Phosphate } \\
\text { Solubilization Index }\end{array}$ & 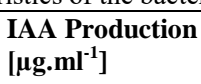 & Siderophore Production & $\begin{array}{l}\text { Protection against } \\
\text { pathogens [\%] }\end{array}$ \\
\hline 231 & $2.14 \pm 0.08$ & $5.60 \pm 0.13$ & + & $55.93 \pm 0.03$ \\
\hline 239 & $2.52 \pm 0.19$ & $2.81 \pm 0.18$ & + & $59.70 \pm 0.12$ \\
\hline 246 & $2.01 \pm 0.04$ & $2.07 \pm 0.06$ & + & $57.04 \pm 0.06$ \\
\hline 525 & $2.03 \pm 0.09$ & $2.15 \pm 0.02$ & + & $52.73 \pm 0.08$ \\
\hline
\end{tabular}

Legend: 231 - Bacillus megaterium, 239 - Bacillus flexus, 246 - Bacillus subtilis, 525 - Pseudomonas simiae WCS417

(Netherlands), IAA - indole-3-acetic acid

The application of Bacillus strains can enhance the plant-available forms of nutrients, promote plant growth (roots elongation) and control disease-causing pathogenic microbial growth (Garcia-Fraile et al., 2015). We applied Bacillus strains on maize seeds. The plants were placed in the cultivation chamber and growth under controlled conditions. All 3 Bacillus strains tested in this study exhibit the potential to increase plant growth in in vivo experiments (root length, weight of the young plant) which was also confirmed statistically. The length of the root system increased by more than $18.52 \%$ (B. megaterium), $29.63 \%$ (B. flexus) and $36.6 \%$ (B. subtilis) compared to the control. Weight of the young plant increased by more than $400 \%$ after application of B. subtilis and almost $600 \%$ after application of B. megaterium and B. flexus strain. According to Zamioudis et al. (2013) study, colonization of Arabidopsis roots by Pseudomonas simiae WCS417 promotes plant growth by driving auxindependent developmental changes in root architecture, resulting in the stimulation of lateral root emergence and root hair formation. In our study, all strains produced IAA, although in different amounts. Pseudomonas simiae WCS417, which was used as positive control, promoted plant growth less than other tested bacteria. The length of the root system was extended by $12 \%$ and the amount of weight of young plant increased almost threefold compared to the control. Bacillus strains that produced lower levels (246 - Bacillus subtilis, 239 Bacillus flexus), had bigger influence on root elongation and biomass, characteristics of great interest that provide greater surface area for the absorption of nutrients. According to Arshad and Frankenberger (1991) the effects of the auxin depend on its concentration, i.e. when it is low it can stimulate growth and when it is high can be inhibitory, same for seed germination. Microbial synthesis and secretion of IAA significantly increase the root length in all cases and play important role in the germination event of various plant species. Weight of the young plant increases in all tested samples, too.
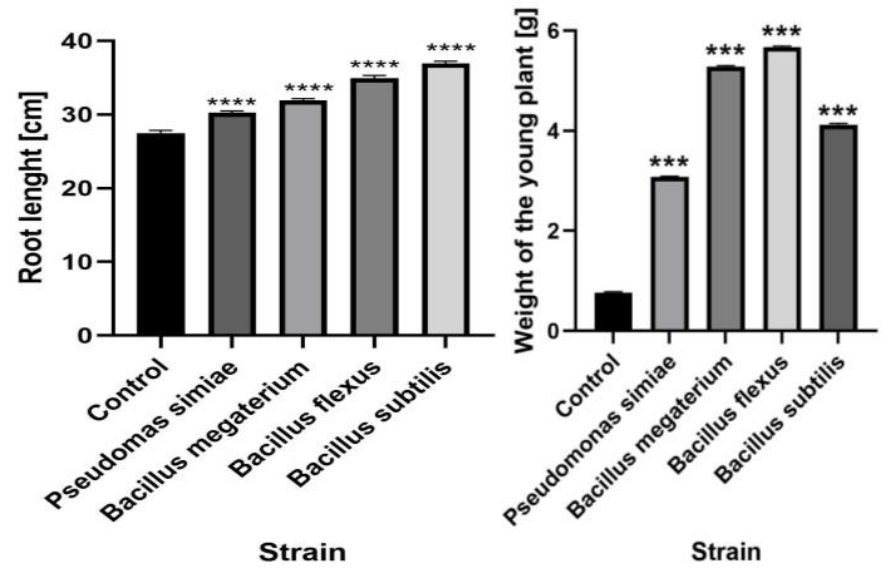

Figure 2 Effects of Bacillus tested strains and reference strain Pseudomonas simiae WCS417 on maize growth (root length and weigth of the young plant) according to the control

According to the all tested direct and indirect plant growth promoting traits and potential of bacteria to promote root length and weight of the young plant we evaluated as the most productive Bacillus flexus strain (239). Results of all tested strains are shown in Table 4

Table 4 Summarizing the results of the tested bacteria strains - plant growth promoting trates and promotion of the root length and weight of the young plant

\begin{tabular}{llllllll}
\hline Sample Code & IAA & PSI & SP & PAP & RL & YP & Total \\
\hline $\mathbf{5 2 5}$ & 3. & 3. & + & 4. & 4. & 4. & 4. \\
$\mathbf{2 3 1}$ & 1. & 2. & + & 3. & 3. & 2. & 2. \\
$\mathbf{2 3 9}$ & 2. & 1. & + & 1. & 2. & 1. & $\mathbf{1}$ \\
$\mathbf{2 4 6}$ & 4. & 3. & + & 2. & 1. & 3. & 3. \\
\hline
\end{tabular}

Legend: IAA- Indole-3-acetic acid, PSI-Phosphate Solubilization Index, SP-Siderophore Production, PAPProtection against Pathogens, RL-Root Length, YP - Weight of the young plant, 525 - Pseudomonas simiae WCS 417, 231 - Bacillus megaterium, 239 - Bacillus flexus, 246 - Bacillus subtilis

\section{CONCLUSION}

Several strains of Bacillus genera are well-established model organisms for research on molecular plant-microbe interactions. Many species are well-known plant-growth promoters. In our study we tested Bacilus flexus, Bacillus subtilis and Bacillus megaterium strains isolated from maize roots. All tested strains showed positive results in laboratory experiment and in vivo experiment According to this fact application of Bacillus as biofertilizer for agriculture improvement can reduce the use of agrochemicals and support eco-friendly crop production. Bacillus sp. having antagonistic and resistance-inducing trait might be useful in formulation of novel bioinoculants leading to almost effective for biocontrol strategies for improving crop growth. Continued research with Bacillus genera has potential for developing biofertilizer and biocontrol agents.

Acknowledgement: Work was supported by the project VEGA no. 1/0661/19: Plant microbiome and safe food and KEGA no. 013SPU-4/2020: Implementation of research results from environmental and applied microbiology into the teaching process and creation of new study materials at II. and III. University degree.

\section{REFERENCES}

Afzal, I., Shinwari, Z. K., Sikandar, S., \& Shahzad, S. (2019). Plant beneficial endophytic bacteria: Mechanisms, diversity, host range and genetic determinants. Microbiological https://doi.org/10.1016/j.micres.2019.02.001
Akram, M. S., Shahid, M., Tariq, M., Azeem, M., Javed, M. T., Saleem, S., \& Riaz, S. (2016). Deciphering Staphylococcus sciuri SAT-17 mediated antioxidative defense mechanisms and growth modulations in salt stressed maize $\begin{array}{lllll}\text { (Zea mays } & \text { L.). Frontiers in } & \end{array}$ https://doi.org/10.3389/fmicb.2016.00867

Arshad, M., \& Frankenberger, W. T. (1991). Microbial production of plant hormones. In The rhizosphere and plant growth (pp. 327-334). Springer, Dordrecht. https://doi.org/10.1007/BF00011893

Beauregard, P. B., Chai, Y., Vlamakis, H., Losick, R., \& Kolter, R. (2013). Bacillus subtilis biofilm induction by plant polysaccharides. Proceedings of the National Academy of Sciences, 110(17), E1621E1630. https://doi.org/10.1073/pnas.1218984110

Berendsen, R. L., van Verk, M. C., Stringlis, I. A., Zamioudis, C., Tommassen, J., Pieterse, C. M., \& Bakker, P. A. (2015). Unearthing the genomes of plantbeneficial Pseudomonas model strains WCS358, WCS374 and WCS417. BMC genomics, 16(1), 539. 10.1186/s12864-015-1632-Z

Bidondo, L. F., Bompadre, J., Pergola, M., Silvani, V., Colombo, R., Bracamonte, F., \& Godeas, A. (2012). Differential interaction between two Glomus intraradices strains and a phosphate solubilizing bacterium in maize rhizosphere. Pedobiologia, 55(4),

https://doi.org/10.1016/i.pedobi.2012.04.001

Collins, CH., Lyne, PM., Grange, JM., Falkinham, JO. (2004). Colin's \& Lyne's Microbial Methods, 8 th edition, London. ISBN 0340808969.

Desrut, A., Moumen, B., Thibault, F., Le Hir, R., Coutos-Thévenot, P., \& Vriet C. (2020). Beneficial rhizobacteria Pseudomonas simiae WCS417 induce major 
transcriptional changes in plant sugar transport. Journal of Experimental Botany, 71(22), 7301-7315. 10.1093/jxb/eraa396

Edgar, R. C. (2004). MUSCLE: multiple sequence alignment with high accuracy and high throughput. Nucleic acids research,32(5), 1792-1797. https://doi.org/10.1093/nar/gkh340

García-Fraile, P., Menéndez, E., \& Rivas, R. (2015). Role of bacterial biofertilizers in agriculture and forestry. AIMS Bioengineering,2(3), 183 10.3934/bioeng.2015.3.183

Glick, B. R. (1995). The enhancement of plant growth by free-living bacteria. Canadian Journal of Microbiology,41(2), 109-117. https://doi.org/10.1139/m95-015

Glick, B. R. (2014). Bacteria with ACC deaminase can promote plant growth and help to feed the world. Microbiological research, 169(1), 30-39. https://doi.org/10.1016/j.micres.2013.09.009

Gordon, S. A., \& Weber, R. P. (1951). Colorimetric estimation of indoleacetic acid. Plant Physiology, 26(1), 192. https://doi.org/10.1104/pp.26.1.192 Gupta, R., Singal, R., Shankar, A., Kuhad, R. C., Saxena, R. L. (1994). A modified plate assay for screening phosphate solubilizing microorganisms. The Journal of General and Applied Microbiology,40(3), 255-260. https://doi.org/10.2323/igam.40.255

Hallmann, J., \& Berg, G. (2006). Spectrum and population dynamics of bacteria root endophytes. In Microbial root endophytes (pp. 15-31). Springer, Berlin, Heidelberg. https://doi.org/10.1007/3-540-33526-9

Javoreková, S., Cinkocki, R., Maková, J., Hricáková, N. (2020). Isolation and identification of rhizobacteria from Maize (zea mays L.) in luvisols and documentation their plant growth promoting traits. In Journal of Microbiology, Biotechnology and Food Sciences. 10(3), 505-510. doi:10.15414/jmbfs.2020.10.3.505-510

Jones, K. M., Kobayashi, H., Davies, B. W., Taga, M. E., \& Walker, G. C. (2007). How rhizobial symbionts invade plants: the Sinorhizobium-Medicago model. Nature Reviews Microbiology, 5(8), 619-633. 10.1038/nrmicro1705

Kang, C. H., Oh, S. J., Shin, Y., Han, S. H., Nam, I. H., \& So, J. S. (2015) Bioremediation of lead by ureolytic bacteria isolated from soil at abandoned metal mines in South Korea. Ecological Engineering, 74, 402-407. https://doi.org/10.1016/j.ecoleng.2014.10.009

Kobayashi, D. Y., \& Palumbo, J. D. (2000). Bacterial Endophytes and Their. Microbial endophytes, 2000, 99-233. 10.12691/jaem-4-5-2

Kuan, K. B., Othman, R., Abdul Rahim, K., \& Shamsuddin, Z. H. (2016). Plant growth-promoting rhizobacteria inoculation to enhance vegetative growth nitrogen fixation and nitrogen remobilisation of maize under greenhouse conditions. Plos

$\mathrm{e} 0152478$.

Kumar, V., \& Narula, N. (1999). Solubilization of inorganic phosphates and growth emergence of wheat as affected by Azotobacter chroococcum mutants. Biology and Fertility of Soils, 28(3), 301-305. https://doi.org/10.1007/s003740050497

Kumar, S., Stecher, G., Li, M., Knyaz, C., \& Tamura, K. (2018). MEGA X molecular evolutionary genetics analysis across computing platforms. Molecula Biology and Evolution, 35(6),

1547-1549.

https://doi.org/10.1093/molbev/msy096

Lalande, R., Bissonnette, N., Coutlée, D., \& Antoun, H. (1989). Identification of rhizobacteria from maize and determination of their plant-growth promoting potential. Plant and Soil, 115(1), 7-11. https://doi.org/10.1007/BF02220688

Lyngwi, N. A., \& Joshi, S. R. (2014). Economically important Bacillus and related genera: a mini review. Biology of useful plants and microbes, 3, 33-43. 10.12691/jaem-8-2-1

Majeed, A., Muhammad, Z., \& Ahmad, H. (2018). Plant growth promoting bacteria: role in soil improvement, abiotic and biotic stress management of crops. Plant Cell Reports, 37(12), 1599-1609. doi: 10.1007/s00299-018-2341-2

Nadeem, M., Mollier, A., Morel, C., Vives, A., Prud'Homme, L., \& Pellerin, S. (2012). Seed phosphorus remobilization is not a major limiting step for phosphorus nutrition during early growth of maize. Journal of Plant Nutrition and Soil Science, 175(6), 805-809. https://doi.org/10.1002/jpln.201200369

Nardi, S., Morari, F., Berti, A., Tosoni, M., \& Giardini, L. (2004). Soil organic matter properties after 40 years of different use of organic and minera fertilisers. European Journal of Agronomy,21(3), 357-367. https://doi.org/10.1016/j.eja.2003.10.006

Nautiyal, C. S., Srivastava, S., Chauhan, P. S., Seem, K., Mishra, A., \& Sopory, S. K. (2013). Plant growth-promoting bacteria Bacillus amyloliquefacien NBRISN13 modulates gene expression profile of leaf and rhizosphere community in rice during salt stress. Plant Physiology and Biochemistry, 66, 1-9. https://doi.org/10.1016/j.plaphy.2013.01.020

Numan, M., Bashir, S., Khan, Y., Mumtaz, R., Shinwari, Z. K., Khan, A. L., Ahmed, A. H. (2018). Plant growth promoting bacteria as an alternative strategy for salt tolerance in plants: a review. Microbiological research, 209, 21-32. https://doi.org/10.1016/j.micres.2018.02.003

Olanrewaju, O. S., Glick, B. R., \& Babalola, O. O. (2017). Mechanisms of action of plant growth promoting bacteria. World Journal of Microbiology and Biotechnology, 33(11), 1-16. doi: 10.1007/s11274-017-2364-9
Olivares, F. L., Busato, J. G., De Paula, A. M., da Silva Lima, L., Aguiar, N. O. \& Canellas, L. P. (2017). Plant growth promoting bacteria and humic substances: crop promotion and mechanisms of action. Chemical and Biological Technologies in Agriculture, 4(1), 1-13. https://doi.org/10.1186/s40538-017 $0112-\mathrm{X}$

Pereira, P., Ibáñez, F., Rosenblueth, M., Etcheverry, M., \& Martínez-Romero, E (2011). Analysis of the bacterial diversity associated with the roots of maize (Zea mays L.) through culture-dependent and culture-independent methods. International Scholarly Research Notices, 2011 https://doi.org/10.5402/2011/938546

Pieterse, C. M., Berendsen, R. L., de Jonge, R., Stringlis, I. A., Van Dijken, A. J., Van Pelt, J. A., \& Bakker, P. A. (2020). Pseudomonas simiae WCS417: star track of a model beneficial rhizobacterium. Plant and Soil, 1-19. https://doi.org/10.1007/s11104-020-04786-9

Radhakrishnan, R., \& Lee, I. J. (2016). Gibberellins producing Bacillus methylotrophicus KE2 supports plant growth and enhances nutritional metabolites and food values of lettuce. Plant Physiology and Biochemistry, 109, 181-189. https://doi.org/10.1016/j.plaphy.2016.09.018

Ramakrishna, W., Yadav, R., \& Li, K. (2019). Plant growth promoting bacteria in agriculture: two sides of a coin. Applied Soil Ecology, 138, 10-18. https://doi.org/10.1016/j.apsoil.2019.02.019

Ratón, T. D. L. M. O., Yano, R., Gámez, O. R., Floh, E. I. S., Díaz, M. D. J. S., \& Barbosa, H. R. (2012). Isolation and characterisation of aerobic endospore forming Bacilli from sugarcane rhizosphere for the selection of strains with agriculture potentialities. World Journal of Microbiology and Biotechnology, 28(4), 1593-1603.

Sharma, H. S., Fleming, C., Selby, C., Rao, J. R., \& Martin, T. (2014). Plant biostimulants: a review on the processing of macroalgae and use of extracts for crop management to reduce abiotic and biotic stresses. Journal of Applied Phycology, 26(1), 465-490.

Schwyn, B., \& Neilands, J. B. (1987). Universal chemical assay for the detection and determination of siderophores. Analytical Biochemistry, 160(1), 47-56. https://doi.org/10.1016/0003-2697(87)90612-9Shrivastava, M., Srivastava, P. C \& D'Souza, S. F. (2016). KSM soil diversity and mineral solubilization, in relation to crop production and molecular mechanism. In Potassium solubilizing microorganisms for sustainable agriculture (pp. 221-234). Springer, New Delhi. DOI: 10.1007/978-81-322-2776-2 16

Stringlis, I. A., Zamioudis, C., Berendsen, R. L., Bakker, P. A., \& Pieterse, C. M. (2019). Type III secretion system of beneficial rhizobacteria Pseudomonas simiae WCS417 and Pseudomonas defensor WCS374. Frontiers in microbiology, 10, 1631. https://doi.org/10.3389/fmicb.2019.01631

Sturz, A. V., Christie, B. R., \& Nowak, J. (2000). Bacterial endophytes: potential role in developing sustainable systems of crop production. Critical reviews in plant sciences, 19(1), 1-30. https://doi.org/10.1080/07352680091139169

Sun, J., Smith, L., Armento, A., Deng, W.M. (2008). Regulation of the endocycle/gene amplification switch by Notch and ecdysone signaling. Journal of Cell Biology. 182(2), 885-896. https://doi.org/10.1083/jcb.200802084

Tamura, K., Dudley, J., Nei, M., \& Kumar, S. (2007). MEGA4: molecular evolutionary genetics analysis (MEGA) software version 4.0. Molecular Biology and Evolution, 24(8), 1596-1599. https://doi.org/10.1093/molbev/msm092

Tonelli, M. L., Magallanes-Noguera, C., \& Fabra, A. (2017). Symbiotic performance and induction of systemic resistance against Cercospora sojina in soybean plants co-inoculated with Bacillus sp. CHEP5 and Bradyrhizobium japonicum E109. Archives of Microbiology, 199(9), 1283-1291. https://doi.org/10.1007/s00203-017-1401-2

Williams, A., Pétriacq, P., Beerling, D. J., Cotton, T. E., \& Ton, J. (2018) Impacts of atmospheric $\mathrm{CO} 2$ and soil nutritional value on plant responses to rhizosphere colonization by soil bacteria. Frontiers in Plant Science, 9, 1493 https://doi.org/10.3389/fpls.2018.01493

Yu, K., Liu, Y., Tichelaar, R., Savant, N., Lagendijk, E., van Kuijk, S. J., \& Berendsen, R. L. (2019). Rhizosphere-associated Pseudomonas suppress local root immune responses by gluconic acid-mediated lowering of environmental $\mathrm{pH}$ Current Biology, 29(22), 3913-3920. https://doi.org/10.1016/j.cub.2019.09.015 Zamioudis, C., Mastranesti, P., Dhonukshe, P., Blilou, I., \& Pieterse, C. M (2013). Unraveling root developmental programs initiated by beneficia Pseudomonas spp. bacteria. Plant Physiology, 162(1), 304-318. https://doi.org/10.1104/pp.112.212597 